Bias in resulting estimate of distribution

It is perhaps more surprising that any method of estimating the time of infection by a single time point will result in the estimation of a biased distribution of incubation time. The exact resulting perturbation of the distribution is difficult to predict but plainly, for example, the variance will be overestimated, as the times subject to analysis will have one variance component in themselves (the natural variability of incubation times) and one additional variance component from the estimation of the time of infection. This second source of variance must of necessity be greater than zero, as the true times of infection are unknown. Taylor et al tried to correct for this effect, ${ }^{17}$ but we believe that the resulting distribution remains biased. We do not, however, know of any other method of correction.

\section{Fitting of distributions}

It is tempting to try to fit known distributional forms to data in order to stabilise estimates and be able to make predictions about the future course of infection. We are not convinced about the soundness of this approach. There is at present no way of choosing the correct distribution, and knowing or being able to estimate the left tail of the incubation times (in this study we barely reached the $10 \%$ level in the cumulative incidence of AIDS) does not carry much information about the central parts of this distribution.

We have checked the applicability of the often used Weibull distribution ${ }^{45}$ as a description of the present data by graphical methods-plotting estimated log cumulative hazard against log time, a plot that should yield approximately straight lines if the Weibull distribution were appropriate-and found that time to the onset of AIDS could be thus described but not time to the occurrence of first symptom. The parametric fitting of Weibull distributions to the haemophiliac and transfusion recipient groups separately, for example, resulted in estimates of the corresponding median incubation times before the onset of AIDS, which were $13 \cdot 4$ (SE 2) and $5 \cdot 7$ (1) years, respectively.
This work has been supported by the Swedish Medical Research Council (grant K87-27H-08175-01) and the Stockholm County Council.

1 Hessol NA, Rutherford GW, O'Malley PM, et al. The natural history of human immunodeficiency virus infection in a cohort of homosexual and bisexual men: a 7-year prospective study [Abstract]. Proceedings of third international conference on AIDS. Washington, DC. US Department of Health and Human Services, 1987:1.

2 Eyster ME, Gail MH, Ballard JO, Al-Mondhiry H, Goedert JJ. Natural history of human immunodeficiency virus infections in hemophiliacs: effects on T-cell subsets, platelet counts and age. Ann Intern Med 1987;107:1-6.

3 Peterman TA, Holmberg SD, Lui K-J. Transfusion-associated AIDS in the United States [Abstract]. Proceedings of third international conference on AIDS. Washington, DC: US Department of Health and Human Services, 1987:160

4 Lui K-J, Lawrence DN, Morgan WM, Peterman TA, Haverkos HW, Bregman DJ. A model-based approach for estimating the mean incubation period of transfusion-associated acquired immunodeficiency syndrome. Proc Natl Acad Sci USA 1986;83:3051-5.

5 Medley GF, Anderson RM, Cox DR, Billard L. Incubation period of AIDS in patients infected via blood transfusion. Nature 1987;328:719-21.

6 Iversen O-J, Engen S. Epidemiology of AIDS-statistical analyses. 7 Epidemiol Community Health 1986:41:55-8.

7 Rees M. The sombre view of AIDS. Nature 1987;326:343-5.

8 Brookmeyer R, Gail MH. Minimum size of the acquired immunodeficiency syndrome (AIDS) epidemic in the United States. Lancet 1986;ii:1320-2.

9 van Druten JAM, de Boo Th, Jager JC, Heisterkamp SH, Coutinho RA, Ruitenberg EJ. AIDS prediction and intervention. Lancet 1986;i:852-3.

10 Peterman TA, Drotman DP, Curran JW. Epidemiology of the acquired immunodeficiency syndrome (AIDS). Epidemiol Rev 1985;7:1-21.

11 Schulman S, Biberfeld G, Blombäck $M$, et al. HIV infection in a defined population of Swedish haemophiliacs. Scand f Infect Dis 1987;19:159-66.

12 Berntorp E, Hansson BG, Böttiger B, et al. HIV seroconversion in Swedis haemophiliacs: relation to type and dosage of factor concentrate. European fournal of Haematology 1987;38:256-60.

13 Ward JW, Deppe DA, Samson S, et al. Risk of human immunodeficiency virus infection from blood donors who later developed the acquired immunodeficiency syndrome. Ann Intern Med 1987;106:61-2.

14 Berglund O, Beckman S, Grillner L, et al. HIV transmission by blood transfusions in Stockholm 1979-1985: nearly uniform transmission from infected donors. AIDS (in press).

15 Cox DR, Oakes D. Analysis of survival data. London and New York: Chapman and Hall, 1984

16 Ward JW, Deppe D, Perkins H, Kleinman S, Holland P, Allen J. Risk of disease in recipients of blood from donors later found infected with human immunodeficiency virus (HIV) [Abstract]. Proceedings of third international conference on AIDS. Washington, DC: US Department of Health and Human Services, 1987:2.

17 Taylor JMG, Schwartz K, Detels R. The time from infection with human immunodeficiency virus (HIV) to the onset of AIDS. $f$ Infect $D$ t 1986;154:694-7.

18 Goedert JJ, Landesman SH, Eyster ME, Biggar RJ. AIDS incidence in pregnant women, their babies, homosexual men and hemophiliacs [Abstract]. Proceedings of third international conference on AIDS. Washington, DC: US Department of Health and Human Services, 1987:71.

(Accepted 12 April 1988)

\title{
Adhesive Escherichia coli in inflammatory bowel disease and infective diarrhoea
}

\author{
D A Burke, A T R Axon
}

\section{Abstract}

The clinical features of ulcerative colitis and Crohn's disease are similar to those of infections of the bowel, although their cause is uncertain. Many bacteria that cause intestinal diseases adhere to the gut mucosa, and adhesion of pathogenic Escherichia coli is resistant to D-mannose. The adhesive properties of isolates of $\mathbf{E}$ coli were assessed by assay of adhesion to buccal epithelial cells with mannose added. The isolates were obtained from patients with inflammatory bowel diseases ( 50 with a relapse of ulcerative colitis, nine with ulcerative colitis in remission, 13 with Crohn's disease, and 11 with infectious diarrhoea not due to E coli) and 22 controls.

The median index of adhesion to buccal epithelial cells (the proportion of cells with more than $\mathbf{5 0}$ adherent bacteria) for $E$ coli from patients with ulcerative colitis in relapse was significantly higher $(43 \%)$ than that for controls $(5 \%)$ and patients with infectious diarrhoea (14\%). The index was not significantly different among isolates from patients with ulcerative colitis in relapse, Crohn's disease $(53 \%)$, and ulcerative colitis in remission (30\%). If an index of adhesion of $>25 \%$ is taken as indicating an adhesive strain $86 \%$ of isolates of $E$ coli from patients with inflammatory bowel disease were adhesive compared with $27 \%$ from patients with infective diarrhoea and none from controls.

The adhesive properties of the isolates from patients with inflammatory bowel disease were similar to those of pathogenic intestinal $\mathbf{E}$ coli, raising the possibility that they may have a role in the pathogenesis of the condition; the smaller proportion of adhesive isolates in patients with infective diarrhoea due to other bacteria suggests that the organism may be of primary importance rather than arising secondarily.

\section{Introduction}

Mucosal adhesion is a virulence factor that is expressed by pathogenic Escherichia coli in the intestine. Enterotoxigenic strains of $E$ coli are recognised 
pathogens, but in both animals and humans the production of enterotoxin alone is not sufficient to produce disease in all cases. ${ }^{12}$ Intimate mucosal association is necessary for the pathogenicity of enterotoxigenic $E$ coli to be fully expressed and such strains adhere to intestinal mucosa with the fimbrial antigens colonisation factor antigens I and II, which are plasmid mediated and whose adhesion is resistant to mannose. ${ }^{3.6}$ The mechanisms whereby enteropathogenic $E$ coli that does not produce toxin causes diarrhoea are not fully understood, but again adhesion that is resistant to mannose seems to be essential for pathogenicity. ${ }^{7-12}$ Mucosal adhesion of $E$ coli is also important in non-gastrointestinal disease, being found in strains causing infections of the urinary tract. ${ }^{13}$

Dickinson et al, using a HeLa cell technique, showed an adhesive property of $E$ coli isolated from patients with ulcerative colitis, ${ }^{14}$ and this observation has been confirmed by an assay of adhesion to buccal epithelial cells. ${ }^{15}$ It is unclear, however, whether these adhesive organisms are primary pathogens or are secondary to the disease, perhaps arising as a result of altered transit through the bowel or inflamed host tissue.

We assessed the prevalence of $E$ coli showing mannose resistant adhesion in four groups of patients: one group with ulcerative colitis, one with Crohn's disease, one with infective diarrhoea, and a control group.

\section{Patients and methods}

$E$ coli was isolated from the stools of 50 patients who presented with a relapse of ulcerative colitis before treatment of the episode, nine with ulcerative colitis in remission, 13 with Crohn's disease, 11 with infectious diarrhoea (one with salmonellosis and 10 with campylobacter enterocolitis), and 22 controls. The controls comprised staff and patients who were not receiving any treatment and did not have evidence of inflammatory bowel disease. One colony of $E$ coli was chosen at random from each patient to be tested for adhesion. Ten colonies in all were kept from each patient for future analysis. All isolates were stored on slopes of Dorset egg medium and protected from light. $E$ coli E851/71, a non-toxigenic enteropathogenic strain that adheres to Hep 2 cells (originally isolated from a patient with infantile diarrhoea) ${ }^{16}$ and $E$ coli SC13, a recognised non-adhesive strain, were included as standard strains.

Adhesion was determined by assaying adherence of

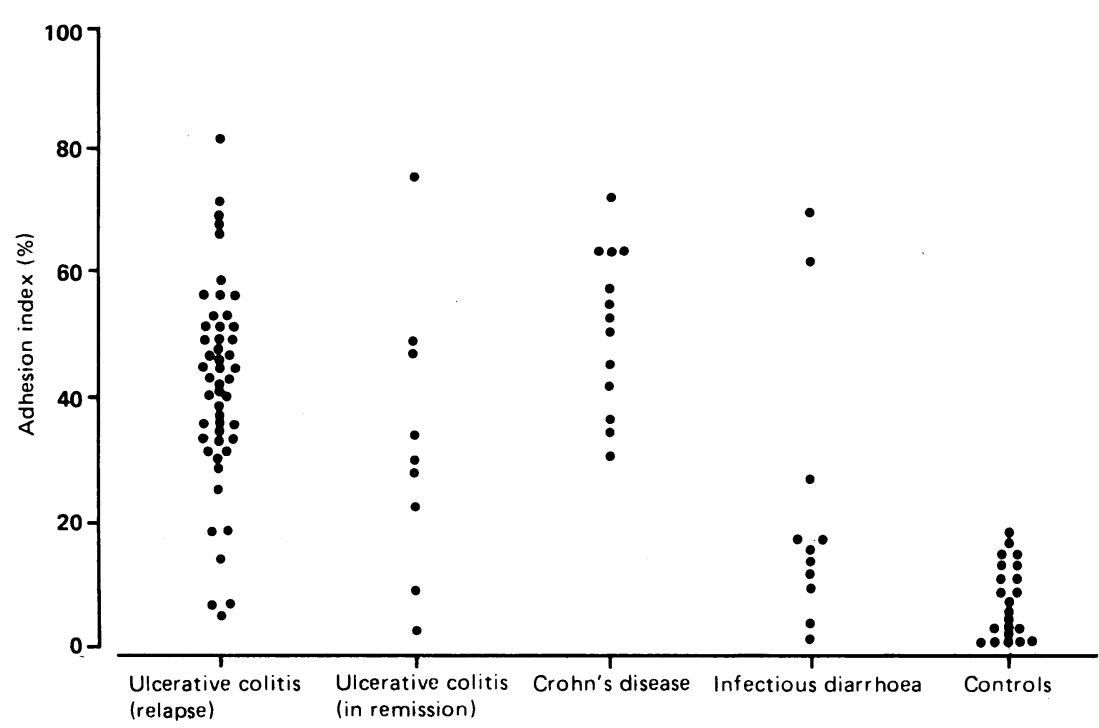

Adhesion index (proportion of buccal epithelial cells showing $>50$ adherent Gram negative bacteria in presence of D-mannose) of isolates of $E$ coli from patients with inflammatory bowel disease and controls the isolates to buccal epithelial cells. Isolates were independently coded and grown for 18 hours at $37^{\circ} \mathrm{C}$ on slopes of Oxoid blood agar base No 2. Buccal epithelial cells were obtained from a single donor by gently scraping the buccal mucosa with a sterile spatula. The cells and bacterial cell suspensions of bacteria were incubated together as previously described at room temperature in the presence of D-mannose. ${ }^{15}$ After incubation the cells were harvested by filtration and washing over a $5 \mu \mathrm{m}$ millipore filter (Nucleopore). An impression smear was made on to a clean glass slide, dried in air, fixed in methanol, and stained by Gram's method. A control comprising epithelial cells without added bacteria was included in each assay.

An index of adhesion was derived by inspecting 100 non-overlapping epithelial cells in at least $10 \mathrm{high}$ power fields and recording the number with more than 50 adherent Gram negative rods minus the number of such cells present in the control. Results are expressed as the proportion of buccal cells with more than 50 adherent bacteria. Statistical analysis was by the Mann-Whitney U test.

\section{Results}

The figure shows the index of adhesion of the $E$ coli isolates. The median index of $E$ coli isolated from patients with a relapse of ulcerative colitis was significantly higher $(43 \%$, range $5-81 \%)$ than that for controls $(5 \%, 0-16 \% ; \mathrm{p}<0.001)$ and infectious diarrhoea $(14 \%, 0-68 \% ; p<0.005)$ but not significantly different from that of isolates from patients with Crohn's disease $(53 \%, 30-71 \%)$ and ulcerative colitis in remission $(30 \%, 2-75 \%)$. There was no significant difference between the index of adhesion of $E$ coli isolated from patients with a relapse of ulcerative colitis who were receiving sulphasalazine $(n=22)$ and those who were not $(n=28)$. The mean index of adhesion of the standard control strains, E851/71 and SC13, was $47 \%$ and $6 \%$, respectively.

Previous workers have taken an index of adhesion to buccal epithelial cells of $>25 \%$ to differentiate between adhesive and non-adhesive strains. ${ }^{17}$ By this criterion $86 \%$ of our isolates from patients with inflammatory bowel disease were adhesive strains compared with $27 \%$ from patients with infectious diarrhoea and none from the controls.

\section{Discussion}

The clinical features of ulcerative colitis and Crohn's disease in relapse are similar to those of dysentery and other infectious colitides. ${ }^{18-21}$ The intimate association of micro-organisms with the colonic mucosa and the difficulties in inducing experimental colitis in germ free animals suggest that bacteria may have a role in the pathogenesis of inflammatory bowel disease. ${ }^{22}$ Several studies in which the proportion of $E$ coli to other viable bacteria was compared in inflammatory bowel disease and controls have reported conflicting results. ${ }^{23-26}$ Indeed, diarrhoea from any cause may alter the relative proportion of organisms in the faeces. ${ }^{27} \mathrm{~A}$ more relevant approach is to look for qualitative differences between organisms isolated from patients and controls.

Our finding that a significant proportion of patients with inflammatory bowel disease harboured in their stools $E$ 'coli with an adhesive property resistant to mannose that was reminiscent of that expressed by recognised pathogenic $E$ coli suggests that this organism may have a role in the pathogenesis of inflammatory bowel disease. An alternative explanation is that it was acquired secondarily. The difference in the proportion of adhesive $E$ coli present between the group with inflammatory bowel disease and the 
group with campylobacter enteritis, which also gives rise to intestinal inflammation, does not support this view. Our observation cannot necessarily be extended, however, to other infectious diarrhoeal diseases. In a previous study the proportion of patients carrying adhesive $E$ coli was higher during a first attack of idiopathic colitis than during relapse. ${ }^{28}$ If the disease itself was the underlying cause for the presence of adhesive $E$ coli the reverse might have been expected.

All bacteria were grown and subcultured in vitro, so the adhesive property is not likely to be a transient effect induced by a factor within the gut lumen. The adhesive mechanisms, both fimbrial and afimbrial, described for recognised pathogenic intestinal $E$ coli are genetically controlled: colonisation factor antigens I and II of enterotoxigenic $E$ coli and the enteroadhesive factor of enteropathogenic $E$ coli are mediated by plasmids. ${ }^{329} 12$ This raises the possibility that the adhesive $E$ coli in patients with inflammatory bowel disease acquire the property from some other source. There are anecdotal reports of inflammatory bowel disease occurring after infection with recognised intestinal pathogens. ${ }^{30-32}$ Plasmids coding for virulence factors have been transferred among different strains of $E$ coli and from other pathogenic intestinal bacteria to $E$ coli. ${ }^{333-35}$ Such transfer to commensal $E$ coli in vivo might result in the expression of virulence antigens.

We excluded bacterial adhesion by type 1 fimbrias in this study by including mannose in the adhesion assay and by growing the $E$ coli on a solid medium..$^{36}$ There is no evidence to suggest that fimbrial adhesions sensitive to mannose are associated with the pathogenicity of intestinal $E$ coli in humans.

Controversy exists as to whether Crohn's disease and ulcerative colitis are separate diseases. Interestingly, we found adhesive $E$ coli in similar proportions of patients with both conditions.

There is a long held view that infectious agents may have a role in the pathogenesis of inflammatory bowel disease. Several workers have shown that isolates of $E$ coli obtained from patients with ulcerative colitis can degrade mucins and produce necrotoxins and haemolysins to a greater extent than those from control subjects. ${ }^{23}{ }^{37}$ The qualitative differences between $E$ coli from patients with inflammatory bowel disease and the normal faecal flora observed in this and previous

\section{Correction}

Does low entry of cystic duct predispose to stones in the common bile duct?

We regret that the radiograph in this article by Professor PC Bornman and others ( 2 July, p 31) was left out of some copies of the $B M \mathcal{F}$. The illustration was correct when passed for press but fell off during the prepress production stage.

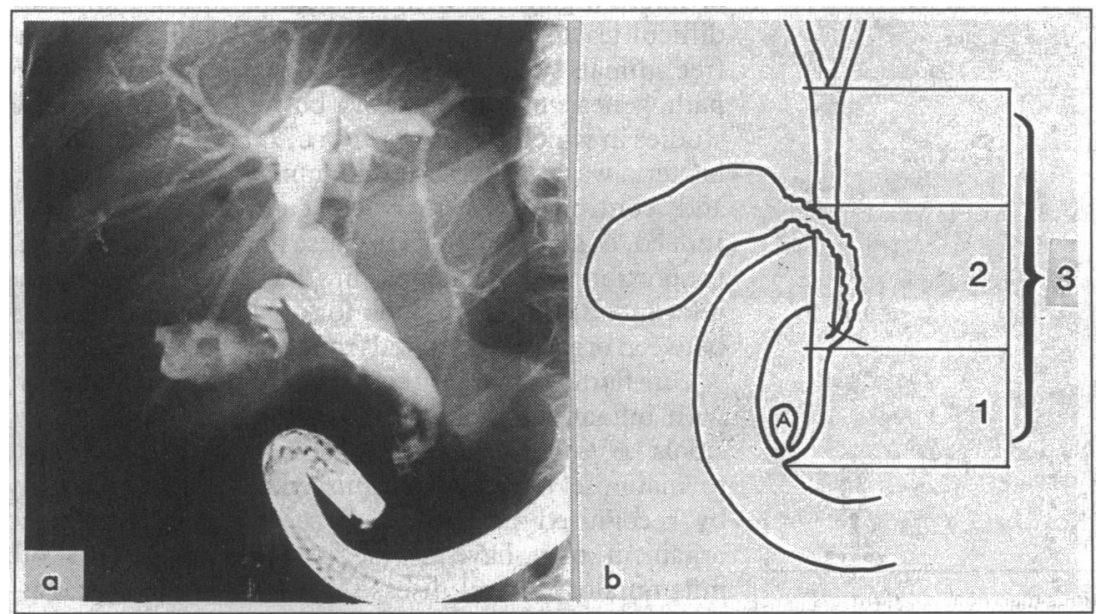

(a) Left sided entry of cystic duct at level of ampulla of Vater. (b) Measurements of segments of bile duct: 1 ampulla of Vater to entry of cystic duct, 2 contiguous segment of cystic duct and common hepatic duct, and 3 total length of bile duct. A =Ampullary diverticulum studies suggest that these strains may have a role in the pathogenesis of the disease.

1 Satterwhite TK, Evans DG, Dupont HL, Evans DJ Jr. Role of Escherichia coli colonisation factor antigen in acute diarrhoea. Lancet 1978;ii:181-4.

2 Smith HW, Linggood MA. Observations on the pathogenic properties of the K88, Hly and Ent plasmids of Escherichia coli with particular reference to porcine diarrhoea. I Med Microbiol 1971;4:467-85.

3 Evans DG, Silver RP, Evans DJ, Chase DG, Gorbach SL. Plasmid controlled colonization factor associated with virulence in Escherichia coli enterocolonization factor associated

Evans DH, Evans DJ. New surface-associated heat-labile colonization factor tigen (CFA-II) produced by enterotoxigenic Escherichia coli of serogroups 06 and 08. Infect Immun 1978;21:638-47.

5 Evans DG, Evans DJ, Tjoa WS, Dupont HL. Detection and characterization of colonization factor of enterotoxigenic Escherichia coli isolated from adults with diarrhoea. Infect Immun 1977;19:727-36.

6 Knutton S, Lloyd DR, Candy DCA, McNeish AS. Adhesion of enterotoxigenic Escherichia coli to human small intestinal enterocytes. Infect Immun 1985;48:824-31.

7 Levine MM, Nalin DR, Hornick RB, et al. Escherichia coli strains that cause diarrhoea but do not produce heat-labile or heat-stable enterotoxins and are non-invasive. Lancet 1978; ;1119-22.

8 McNeish AS, Turner P, Fleming J, Evans N. Mucosal adherence of human enteropathogenic Escherichia coli. Lancet 1975;ii:946-8.

9 Ulshen MH, Rollo JL. Pathogenesis of Escherichia coli gastroenteritis in man-another mechanism. N Engl f Med 1980;302:99-101.

10 Rothbaum R, McAdams AJ, Gianella R, Partin JC. A clinicopathological study of enterocyte-adherent Escherichia coli: a cause of protracted diarrhoea in infants. Gastroenterology 1982;83:441-54.

11 Moon HW, Whipp SC, Argenzio RA, Levine MM, Gianella RA. Attaching and effacing activities of rabbit and human enteropathogenic Escherichia coli in pig and rabbit intestines. Infect I mmun 1983;41:50-1.

12 Levine MM, Nataro JP, Karch H, et al. The diarrhoeal response of humans to some classic serotypes of enteropathogenic Escherichia coli is dependant on a plasmid encoding an enteroadhesive factor. I Infect $D$ is 1985;152:550-9.

13 Parry SH, Rooke DM. Adhesins and colonization factors of Escherichia coli. In: Sussman M, ed. The virulence of Escherichia coli. London: Academic Press, 1985:79-155.

14 Dickinson RJ, Varian SA, Axon ATR, Cooke EM. Increased incidence of faecal coliforms with in vitro adhesive and invasive properties in patients with ulcerative colitis. Gut 1980;21:787-92.

15 Burke DA, Axon ATR. Ulcerative colitis and E coli with adhesive properties. I Clin Pathol 1987;40:782-6.

16 Scotland SM, Richmond JE, Rowe B. Adhesion of enteropathogenic strains of Escherichia coli (EPEC) to Hep-2 cells is not dependant on the presence of fimbriae. FEMS Microbiology Letuers 1983;20:191-5.

17 Candy DCA, Leung TSM, Phillips AD, Harries JT, Marshall WC. Models for studying the adhesion of enterobacteria to the mucosa of the human intestinal tract. In: Elliot $\mathrm{K}, \mathrm{O}^{\prime} \mathrm{C}$ onnor $\mathrm{M}$, Whelan J, eds. Adhesion and microorganism pathogenicity. Tunbridge Wells: Pitman Medical, 1981:72-93. (Ciba Foundation Symposium 80.)

18 Blaser MJ, Berkowitz ID, Laforce FM, Cravens J, Reller LB, Wang WL. Campylobacter enteritis: clinical and epidemiologic features. Ann Intem Med 1979;91:179-85.

19 Vantrappen G, Agg HO, Ponette E, Geboes K, Bertrand PH. Yersinia enteritis and enterocolitis: gastroenterological aspects. Gastroenterology 1977;72: 220-7.

20 Tedesco FJ, Hardin RD, Harper RN, Edwards BH. Infectious colitis endoscopically simulating inflammatory bowel disease: a prospective evalua tion. Gastrointest Endosc 1983;29:195-7.

21 Hurst AF. Ulcerative colitis. Guy's Hospital Reports 1921;71:26-41.

22 Onderdonk AB, Bartlett JG. Bacteriological studies of experimental ulcerative colitis. Am J Clin Nutr 1979;32:258-65.

23 Van der Wiel-Korstanje JAA, Winkler KC. The faecal flora in utcerative colitis. J Med Microbiol 1975;8:491-501.

24 Gorbach SL, Nahas L, Plaut AG, Weinstein L, Patterson JF, Levitan R. Studies of intestinal microflora $v$ Fecal microbial ecology in ulcerative colitis and regional enteritis: relationship to severity of disease and chemotherapy. Gastroenterology 1968;54:575-87.

25 Keighley MRB, Arabi Y, Dimock F, Burdon DW, Allan RN, AlexanderWilliams J. Influence of inflammatory bowel disease on intestinal microflora. Gut 1978;19:1099-104.

26 Cooke EM. A quantitative comparison of the faecal flora of patients with ulcerative colitis and that of normal persons. Joumal of Patholory and Bacteriology 1967;94:439-44.

27 Bacteriology 1967;94:439-44.

28 Pinder IF, Dickinson RJ, Cooke EM, Axon ATR. High incidence of potentially pathogenic E coli in first attack of idiopathic colitis. $G u$ 1983;24:A997.

29 Penaranda ME, Mann MB, Evans DG, Evans DJ. Transfer of an ST:LT:CFA/II plasmid into Escherichia coli K12 strain RRI by cotransformation with pSC301 plasmid DNA. FEMS Microbiology Lethers 1980;8: $251-4$

30 Steward GT. Post-dysenteric colitis. Br Med J 1950;i:405-9.

31 Powell SJ, Wilmot AJ. Ulcerative post-dysenteric colitis. Gut 1966;7;438-43.

32 Felson J, Gorenberg H. Chronic dysentery, distal ileitis and ulcerative colitis. A follow-up of the Jersey City epidemic of bacillary dysentery. $A m \mathcal{J ~ M e d ~ S a i ~}$ 1936;192:553-6.

33 Williams PH, Sedgwick MI, Evans N, Turner DJ, George RH, McNeish AS. Adherence of an enteropathogenic strain of Escherichia coli to human intestinal mucosa is mediated by a colicinogenic conjugative plasmid. Infect Immun 1978;22:393-402.

44 Orskov I, Orskov F. Episome-carried surface antigen K88 of Escherichia coli. 7 Bacteriol 1966;91:69-75.

35 Sansonetti PJ, Hale TL, Dammin GJ, Kapfer C, Collins HH Jr, Formal SB. Alterations in the pathogenicity of Escherichia coli K12 after transfer of plasmid and chromosomal genes from Shigella flexneri. Infect Imomun 1983;39:1392-402.

36 Duguid JP, Clegg S, Wilson MI. The fimbrial and non-fimbrial haemaglutinins of Escherichia coli. I Med Microbiol 1979;12:213-27.

37 Cooke EM, Ewins SP, Hywel-Jones J, Lennard-Jones JE. Properties of strains of Escherichia coli carried in different phases of ulcerative colitis. Gut 1974;15:143-6.

(Accepted 12 April 1988) 